\title{
Modelling ICT integration in teacher education courses using distributed cognition as a framework
}

\author{
Carole Steketee \\ The University of Notre Dame Australia
}

Teacher education students have a significant role to play in the sustained application of ICT in schools. It is imperative therefore, that they are exposed to effective use of ICT in their training. However, 'effective use' is subjective and existing characterisations of this construct appear to drive different ICT implementation plans adopted by teacher education institutions (Steketee, 2005). While most of these plans have achieved varying degrees of success, the 'integration approach', has been the most promising. By integrating ICT as a learning resource during regular classes, lecturers are exposing students to innovative ways of learning. This exposure, however, must be supported by a relevant implementation framework if the potential of ICT is to be realised. The distributed learning environment framework (DLE) provides this support as it gives lecturers insight into what their classroom context should look and feel like if they are to encourage students to access technology as powerful learning tools. The principles underlying the DLE are explored in this paper. The learning outcomes to emerge from its introduction of an electronic concept-mapping tool into a teacher-education program are also discussed. These outcomes suggest that the DLE is a valuable catalyst for the successful application of ICT in teacher training, and subsequently in schools.

\section{The mediational nature of learning}

Reviews of the literature suggest that the principles underpinning social constructivism effectively support learning with ICT (Maor, 2004). This perspective establishes learning as a social experience (Jonassen, Howland, Moore \& Marra, 2003) and posits that mediational tools (such as ICT) transform the ways in which individuals interact with one another and with their learning environment in general.

The precise way in which ICT mediates learning is not altogether clear in the literature, nor are existing interpretations agreed upon. While most 
theorists agree that ICT 'supports' cognition, it is their interpretation of 'support' that varies. These variances usually relate to claims that ICT can either amplify or augment cognition. Advocates of the amplification perspective claim that ICT supports cognition by carrying out lower order cognitive tasks, leaving the student free to carry out more complex cognitive tasks (Jonassen, 1992).

Advocates of the augmentation perspective, however, claim that ICTs support cognition by offering students opportunities to construct more sophisticated representations of phenomena (Pea, 1985; 1993). Others argue that ICTs have a residual effect in the sense that they equip students with new tools of thought which can be accessed even when the ICT is not present (Salomon, Perkins \& Globerson, 1991; Underwood \& Underwood, 1990).

Given that any one of these outcomes is possible depending on the capabilities of the applications being accessed, and the ways in which they are being used (Knuth \& Cunningham, 1993), the 'amplification/ augmentation/ residual' argument becomes a superfluous one. In light of the fact that the ICT can transform activity upon the world (Crook, 1994; Somekh, 2001), perhaps a more pertinent question is "how can teachers cultivate mediations between the ICT and students" such that opportunities to expand cognition are seized upon?

\section{Distributed cognition}

Distributed cognition, which stems from social constructivism, provides an opportunity for exploring this question further. The premise of this construct is that learning is not a sole pursuit but is shared with mediating resources found within the learning environment. In essence, learning is distributed across minds that are connected by way of the activity within which they are collectively participating. No one particular entity embodies knowledge, rather it is a property of the student's engagement with the specific situation at hand; it is spread over the entire context which includes people, resources, rituals and culture (Hutchins, 2000; Rogers, 2004). Duffy \& Cunningham (1996) write, "Thinking ... is always dialogic, connected to another, either directly as in some communicative action or indirectly via some form of semiotic mediation: signs and/or tools appropriated from the sociocultural context" (p. 177).

According to Cole and Engeström (1993), the precise way in which cognition is distributed depends on the tools (resources) available within the environment. These tools, which have been shaped by the culture of the environment, are the means through which students gain access to, and interpret their world. In this way, learning can be described as "a process 
of tuning into the affordances of the environment" (Resnick, 1996, p. 43) and working with them in an effort to develop new understandings. These new understandings will affect subsequent learning situations, and so it can be said that "Cultural mediation has a recursive, bidirectional effect; mediated activity simultaneously modifies both the environment and the subject" (Cole \& Engeström, 1993, p. 9). Salomon (1993) and Salomon and Perkins (1998) refer to this bi-directional effect as a spiral of reciprocal relations between socially distributed understandings, mediating resources and individual cognition.

The mediating resources typically present within learning environments can be described as either the student's intellectual resources (eg., prior knowledge, metacognitive knowledge), social resources (eg., the teacher, peers), symbolic resources (eg., language and symbols representative of the subject being studied), and physical resources (eg., textbooks, ICT). For example, when a student is presented with a learning task, he or she usually considers it in light of existing knowledge on the subject. This existing knowledge is then cultivated in conjunction with other students and classroom resources. For instance, given the chance the student will collaborate with the teacher and peers, as well as available physical resources such as textbooks and/or notebooks, he or she will employ language and symbols representative of the subject at hand, while simultaneously using his or her metacognitive knowledge to monitor progress and call upon learning strategies as required. These resources mediate the student's thinking and learning on the subject and contribute to his or her developing understanding. This revised understanding in turn influences execution of future learning tasks, and the cycle begins again. Figure 1 represents this process diagrammatically.

Similarities can be drawn between this distribution process and Siemen's theory of connectivism which attempts to provide insight into how learning occurs in a digital age (2004). Siemens writes, "The starting point of connectivism is the individual. Personal knowledge is comprised of a network, which feeds into organizations and institutions, which in turn feed back into the network, and then continue to provide learning to individual". As such, learning is a cycle of knowledge development that occurs as a result of the connections individuals make with other networks of knowledge. In a DLE, it can be argued that social, physical, symbolic and intellectual resources are networks of knowledge that feed the individual's own knowledge network which is dynamic as a result of the cyclical process.

Quite often, classroom practices do not reflect the distributed practices described above. In fact, it can be argued that learning activities within many classrooms support individual thinking and learning practices only. 
This is evident in the emphasis schools place on the success achieved by students without the assistance of resources. For example, consider a typical examination situation where students are expected to perform in isolation from their notes, textbooks and peers. While many justifications for this situation exist, Pea's (1993) assertion that resources have been taken for granted is also pertinent. He writes "[resources] have become so deeply a part of our consciousness that we do not notice them. Turned from history into nature, they are invisible, un-'remarkable' aspects of our experiential world" (p.53).

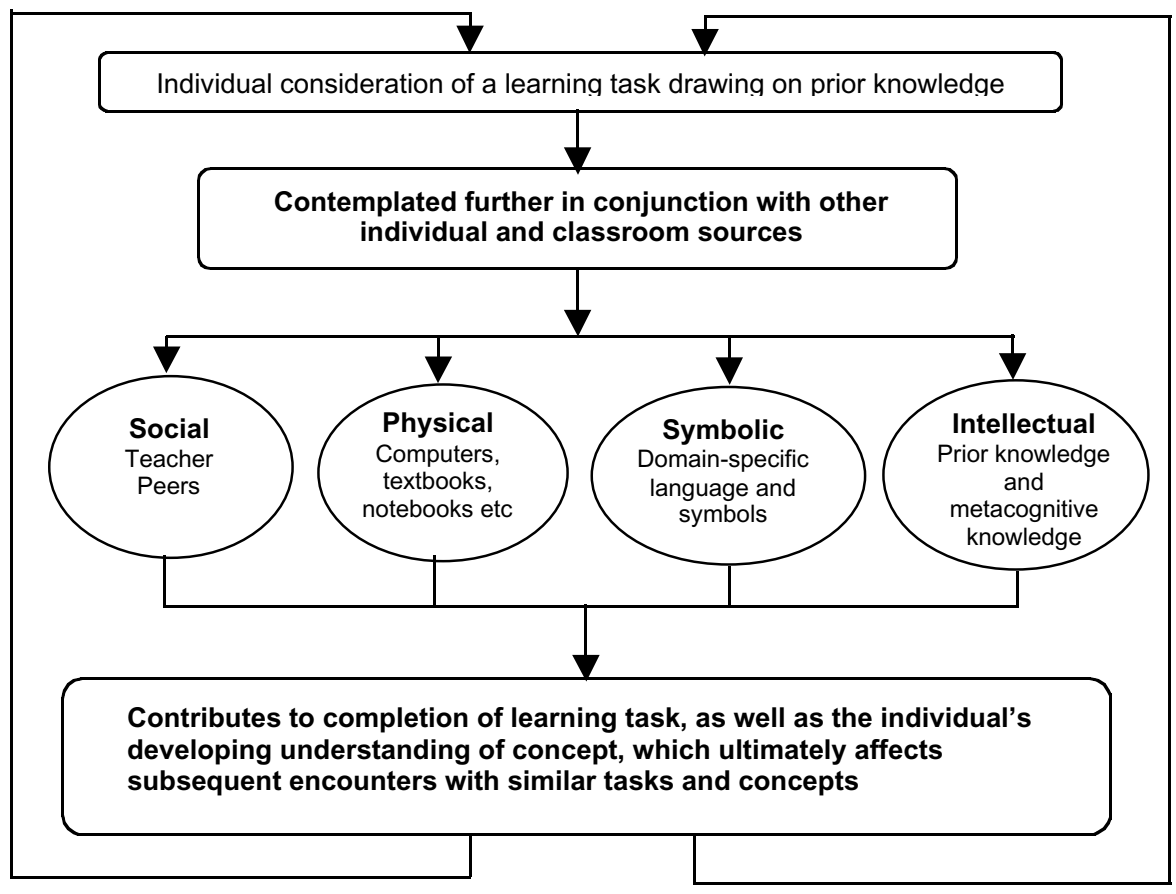

Figure 1: The distribution of cognition across a variety of resources found within classroom learning environments

While it is possible for students to pursue learning tasks drawing on perhaps only one resource (eg., their prior knowledge), it was the contention of this study that cognition is supported when it is distributed across a variety of resources, ICT included. Conversely, it was assumed that the potential of ICT is exploited when used in conjunction with the student's intellectual resources, social resources, symbolic resources and other physical resources as they function together within a social constructivist, learning environment. 


\section{The fingertip effect}

Can we assume, though, that by simply making social, physical, symbolic and intellectual resources available to students, the opportunities the resources afford will be automatically exploited? This is unlikely according to Perkins (1985, 1992, 1993) and others (Pea, 1985, 1993; Nickerson, 1993). A mistake made by many teachers is the assumption that because resources are available - at students' fingertips so to speak - their potential will be maximised. While the immediate conveniences of resources are often taken advantage of (eg., using the word processor to type a completed story) their full potential is rarely exploited (eg., using the word processor to compose a story and provoke intelligent revision) (Perkins, 1985).

One has only to reflect on the classroom context to see that this concern is real. Television, ICT applications, collaborative and cooperative group work, calculators and other innovations have largely failed due to the assumption that their mere presence will yield immediate and profound transformations in education (Perkins, 1992). The consensus was (and arguably still is), that the opportunities afforded by most of these resources would do the teaching itself - that intervention by the teacher would not be necessary as students would naturally gravitate towards the educational opportunities on offer. As a result of this misconception, some educational initiatives have failed with the consensus being that the resource was of little use after all. According to proponents of distributed cognition, however, the problem is not with the resources but with lack of teacher intervention guiding students to discover these opportunities. Perkins (1992) writes:

The image of simply putting something into place - say, a word processor and seeing wonderful learning experiences unfold organically is seductive. But innumerable lost hopes argue for a more hardheaded posture toward the fingertip effect. We must not expect new technologies, the grouping of students, and like innovations to do the job by themselves. We must accept the responsibility of mediating students' good use of these person-plus resources. (p. 147-148)

In essence, what this means is that the opportunities inherent within resources cannot be taken for granted. In the first place, it cannot be assumed that all resources afford educational opportunities. Secondly, even if resources do afford opportunities, this does not mean students are aware of them and, thirdly, even if students are aware of these opportunities, it cannot be assumed that they will be sufficiently motivated to take them (Perkins, 1985).

For example, the potential of ICT in teacher education courses has been recognised and a variety of approaches have been adopted to expose pre- 
service teachers to this resource. On the whole, however, these approaches have achieved limited success in terms of sustained use in the classroom. While these approaches differ in the way pre-service teachers interact with ICT, they are similar to the extent that ICT has been 'input' into the classroom environment with little or no attempt to mediate subsequent interactions. ICT has been placed at the pre-service teachers' fingertips, so to speak. However, had the teacher engineered the learning context such that pre-service teachers were able to develop intellectual partnerships with each other and the ICT, then the outcomes might have been more successful.

This premise was central to the design of a distributed learning environment (DLE) framework. Based on the principles of distributed cognition, this DLE provides scaffolding for teachers in their efforts to promote the distribution of student thinking and learning across a variety of resources. It provides guidelines on teacher and student characteristics that are fundamental to the effective use of resources as partners in learning, and emphasises the integral role of the teacher, not only as a form of social resource, but as someone who orchestrates and mediates the entire learning process for students.

\section{Methodology}

This DLE framework was subsequently used as a catalyst for the integration of an ICT resource into a pre-service teacher education course. In keeping with the principles of distributed cognition, the DLE acknowledged that resources collectively contribute to cognitive activity in the classroom. Consequently, the methodology needed to acknowledge the indivisible nature of the classroom in this instance. While the computer was a focal point of this study, it was acknowledged that its success depended on many other interdependent variables within the learning environment. In relation to this, Salomon et al. (1991) write, "no computer technology in and of itself can be made to affect thinking. One needs to consider both theoretically and practically, the whole social \& cultural milieu..." (p. 3).

As such, qualitative methodology was used given that its principles are more in tune with, and capable of capturing and expressing, the emergent cognitive activity within a distributed learning environment. It was also thought that qualitative approaches would be more sensitive to the nuances characterising social situations and more likely to provide results that were rich, descriptive and a genuine reflection of the participants' perspectives. More specifically, the procedures associated with action research were followed given that the problem being investigated was within the social setting of the researcher's own class. 


\section{Procedure}

Inspiration, an electronic concept mapping tool, was introduced into a fourth year Bachelor of Education unit that historically was delivered in a traditional, campus based, tutorial fashion over a 13 week semester. The unit itself was designed to introduce students to current theory and research about cognitive learning and information processing.

Concept mapping software was chosen due to the interrelated nature of the concepts and topic modules within the unit. The role of Inspiration was to encourage students to explore these interrelationships and progressively build a comprehensive schema of the unit concepts as a whole. It was anticipated that the descriptive linking facility within Inspiration would facilitate this aim.

In keeping with the principles of the DLE, collaborative group work and whole class discussion was the primary approach to teaching and learning. However, in contrast to previous semesters, these collaborations took place around a computer. For this reason, the entire unit took place in a computer laboratory.

At the commencement of the unit, students were familiarised with the principles of distributed cognition and were taught how to develop concept-maps using Inspiration. Initial instruction was deemed important in light of the 'fingertip effect' and Ferry, Hedberg and Harper's (1998) observations that concept mapping skills do not automatically develop as a consequence of simply using the tool.

The collaborative groups were established according to friendships and were comprised of three students and one computer, the composition of which remained the same throughout the semester. Four of these groups were observed to assess the effects Inspiration had on their learning. On three separate occasions, these groups were audiotaped as they constructed their concept maps and completed class activities. Although not the sole source of data, the transcripts from these class activities were the primary focus of analysis.

\section{Framework for analysis}

The analysis tool was derived from models within the literature that describe varying forms and levels of conceptual growth. Biggs \& Collis' (1989) SOLO Taxonomy, Marton, Dall'Alba \& Beaty's (1993) conceptions of learning, and Jonassen and Tessmer's (1996) learning taxonomy were chosen for their rich descriptions of learning outcomes which can be 
applied to both solo and socio-cognitive processes. In attempting to decide which of these three models would be the most suitable for this study, all three were combined to develop a thorough set of learning characteristics.

Table 1: Analysis tool

\begin{tabular}{|c|c|}
\hline \multicolumn{2}{|r|}{ Types of discourse } \\
\hline \begin{tabular}{|l|} 
Social \\
discourse
\end{tabular} & $\begin{array}{l}\text { On task: Any statement or question which is on task but relates } \\
\text { more to the social interaction of the students than the task itself. } \\
\text { Off task: Any statement or question which is off task. }\end{array}$ \\
\hline $\begin{array}{l}\text { Procedural } \\
\text { discourse }\end{array}$ & $\begin{array}{l}\text { Equipment: Any statement or question which relates to procedures } \\
\text { of the equipment. } \\
\text { Software: Any statement or question which relates to procedures of } \\
\text { the software. } \\
\text { Task: Any statement or question which relates to procedures of the } \\
\text { task. }\end{array}$ \\
\hline $\begin{array}{l}\text { Prestructural } \\
\text { discourse }\end{array}$ & $\begin{array}{l}\text { Statements that are illogical, irrelevant, incorrect or incoherent. } \\
\text { Statements about related declarative knowledge that are isolated } \\
\text { from any other information. Statements that are indicative of } \\
\text { memory recall or recognition of isolated declarative knowledge. }\end{array}$ \\
\hline $\begin{array}{l}\text { Foundational } \\
\text { discourse }\end{array}$ & $\begin{array}{l}\text { Statements that are indicative of a developing understanding- } \\
\text { groups can identify more than one relevant concept and will } \\
\text { endeavour (either successfully or unsuccessfully) to relate these } \\
\text { concepts together. Statements show consistency and congruence } \\
\text { with expert perspectives. }\end{array}$ \\
\hline $\begin{array}{l}\text { Relational } \\
\text { discourse }\end{array}$ & $\begin{array}{l}\text { Statements are indicative of the formation of a diverse, complex } \\
\text { semantic network of interrelated concepts. Knowledge of these } \\
\text { relationships is articulated freely and effectively to others. A range } \\
\text { of strategies are employed to facilitate deep level understandings } \\
\text { of material and explanations are logical, coherent and speedy. }\end{array}$ \\
\hline $\begin{array}{l}\text { Extended } \\
\text { abstract } \\
\text { discourse }\end{array}$ & $\begin{array}{l}\text { Statements indicate the group's ability to apply concepts to a range } \\
\text { of situations using learned operations. There is a sense of } \\
\text { originality emerging and confidence to experiment with concepts } \\
\text { in diverse contexts. Analogies are being drawn, abstract inferences } \\
\text { made, as well as personal theories, all of which are highly plausible } \\
\text { and sophisticated. As a result of these newly formed appreciations, } \\
\text { changes are apparent in the way the group perceives concepts } \\
\text { about certain phenomena. }\end{array}$ \\
\hline $\begin{array}{l}\text { Metacognitive } \\
\text { discourse }\end{array}$ & $\begin{array}{l}\text { Statements reflect knowledge about the group's ability as a } \\
\text { learning entity - its strengths and shortcomings. There is an } \\
\text { awareness of the learning context - what the task requirements are, } \\
\text { what resources are available, how these resources can be used } \\
\text { effectively, and what skills and processes will facilitate successful } \\
\text { completion of the task. This incorporates knowledge and } \\
\text { application of appropriate learning strategies (cognitive, } \\
\text { metacognitive and resource management). Groups are able to } \\
\text { articulate, monitor and regulate their effort, persistence and } \\
\text { willingness to learn. }\end{array}$ \\
\hline
\end{tabular}


Because group discussion was the primary source of data, these combined learning characteristics were then translated into five types of corresponding discourse - prestructural discourse, foundational discourse, relational discourse, extended abstract discourse and metacognitive discourse. Dialogue that could not be classified using the taxonomies was usually in relation to social or procedural matters and so these types of discourse were included in the analysis tool, which is elaborated upon in Table 1.

The unit of analysis was concerned with the cognitive processes to emerge from the groups of students as they interacted with each other and their environment. Therefore, group dialogue was the focus of analysis. The fundamental principles of Miles and Huberman's (1994) three step process of data reduction, data display and conclusion drawing as well as Glaser and Strauss' (cited in Lincoln \& Guba, 1985) constant comparative method were used to guide the analysis process. The Non-numerical Unstructured Data Indexing Searching and Theorising (NUD*IST) program was used as a tool to organise and code the data.

\section{Findings}

One would expect that for the computer to have contributed to quality learning within the distributed learning environment, the students' dialogue would be consistent with the latter, more sophisticated discourse categories. In reality, all categories were represented in the students' dialogue - some to a greater or lesser extent. A summary of the nature and extent of this dialogue is presented in Table 2. Accompanying this summary is a short definition of the category and an example of dialogue taken from the transcripts.

Table 2: Summary of findings

\begin{tabular}{|l|l|l|}
\hline \multicolumn{1}{|c|}{ Category } & \multicolumn{1}{|c|}{ Summary of findings } & \multicolumn{1}{c|}{ Example from transcripts } \\
\hline $\begin{array}{l}\text { Social } \\
\text { discourse } \\
\text { (on-task) }\end{array}$ & $\begin{array}{l}\text { Evident (intermittently) in all } \\
\text { transcripts. Mostly occurred when } \\
\text { students were explaining a concept } \\
\text { and would go off on a tangent to a } \\
\text { related but not very relevant issue. }\end{array}$ & $\begin{array}{l}\text { S1: That's like with my daughter } \\
\text { who was told ... she needed to } \\
\text { vary her reading by the librarian } \\
\ldots \text { she hardly reads anything } \\
\text { anymore and ...(CA2/2G1) }\end{array}$ \\
\hline $\begin{array}{l}\text { Social } \\
\text { discourse } \\
\text { (off task) }\end{array}$ & $\begin{array}{l}\text { Evident (intermittently) in all } \\
\text { transcripts. Usually in the form of } \\
\text { one sentence remarks that generally } \\
\text { would not affect task progress. } \\
\text { Comments often related to students } \\
\text { being tired. }\end{array}$ & $\begin{array}{l}\text { S1: What're we doing? } \\
\text { S2: Can we have a break? }\end{array}$ \\
$\begin{array}{l}\text { S1: I'm going to the Royal Show } \\
\text { Saturday. }\end{array}$ \\
S2: Are you? (CA2/2G1)
\end{tabular}




\begin{tabular}{|c|c|c|}
\hline & $\begin{array}{l}\text { comments were in relation to } \\
\text { hardware and system problems. }\end{array}$ & (CA3/2G3) \\
\hline $\begin{array}{l}\text { Procedural } \\
\text { discourse } \\
\text { (software) }\end{array}$ & $\begin{array}{l}\text { Prevalent throughout all transcripts, } \\
\text { but most significant in the first data } \\
\text { recording session. Many comments, } \\
\text { questions and exclamations made } \\
\text { about how to use the software, and } \\
\text { its various functions. As groups } \\
\text { became more proficient users, these } \\
\text { comments transformed into } \\
\text { statements in relation to their desire } \\
\text { to perform more complex and } \\
\text { creative functions. }\end{array}$ & $\begin{array}{l}\text { S1: Oh don't forget we have to } \\
\text { ask [the teacher] about that little } \\
\text { square we hit last week. } \\
\text { (CA1/2G1) } \\
\text { S1: I'm going to flick through the } \\
\text { pictures here to make this look a } \\
\text { bit better. (CA3/2G1) }\end{array}$ \\
\hline $\begin{array}{l}\text { Procedural } \\
\text { discourse } \\
\text { (task) }\end{array}$ & $\begin{array}{l}\text { Prevalent throughout all transcripts, } \\
\text { albeit to a greater or lesser extent } \\
\text { between groups. Those groups, who } \\
\text { didn't understand task } \\
\text { requirements at the beginning of } \\
\text { lesson, spent much time trying to } \\
\text { grasp the objectives throughout the } \\
\text { rest of the class. }\end{array}$ & $\begin{array}{l}\text { S1: So what are we doing here? } \\
\text { S2: We're just doing implications } \\
\text { of this - how we're going to } \\
\text { organise our classroom to use } \\
\text { this best. } \\
\text { S1: I see. } \\
\text { S2: So [typing] 're-cap what was } \\
\text { learnt in the previous lesson'. } \\
\text { (CA1/2G3) }\end{array}$ \\
\hline $\begin{array}{l}\text { Prestruct- } \\
\text { ural } \\
\text { discourse }\end{array}$ & $\begin{array}{l}\text { Mostly apparent at the introduction } \\
\text { of topic modules where groups } \\
\text { encountered concepts for the first } \\
\text { time (drawing on prior knowledge). } \\
\text { Some comments made would be } \\
\text { based on misconceptions previously } \\
\text { held or simply stating facts that } \\
\text { lacked meaning. }\end{array}$ & $\begin{array}{l}\text { S1: Actually you know } \\
\text { constructivism seems to work } \\
\text { really well in my art classes } \\
\text { because ... it's outcomes based. } \\
\text { You've got to think of the } \\
\text { outcome first before you can } \\
\text { write the program. (CA1/2G1) }\end{array}$ \\
\hline $\begin{array}{l}\text { Foundat- } \\
\text { ional } \\
\text { discourse }\end{array}$ & $\begin{array}{l}\text { The most prevalent type of talk } \\
\text { throughout the semester and across } \\
\text { all groups. Evident when groups } \\
\text { were trying to come to terms with } \\
\text { concepts and their inter- } \\
\text { relationships. Questions were } \\
\text { frequently posed to one another and } \\
\text { to the teacher. In most cases, these } \\
\text { uncertainties were resolved with } \\
\text { assistance from the teacher. } \\
\text { Discussions occurred in conjunction } \\
\text { with the concept map, where its } \\
\text { image was used as a visual prompt } \\
\text { to activate conversations. The } \\
\text { concept-map was used frequently as } \\
\text { a basis for groups attempting to } \\
\text { expand the relationships between } \\
\text { concepts. }\end{array}$ & $\begin{array}{l}\text { S1: Yes I know that but how do } \\
\text { you actually control that?... } \\
\text { S2: ... I've had enough. } \\
\text { S3: But hang on, we've already } \\
\text { got it here [referring to map]. } \\
\text { That's part of what we were } \\
\text { talking about before with elab- } \\
\text { oration and ... rehearsal and } \\
\text { those things that you do to learn } \\
\text { something. } \\
\text { S2: No that was levels of } \\
\text { processing. } \\
\text { S3: Yeah I know but ... } \\
\text { S1: So if you are really thinking } \\
\text { about how you're going to learn } \\
\text { it and trying to be in control you } \\
\text { would try to elaborate like in a } \\
\text { deep level way and not rote learn } \\
\text {... (CAG1) }\end{array}$ \\
\hline
\end{tabular}




\begin{tabular}{|c|c|c|}
\hline $\begin{array}{l}\text { Relational } \\
\text { discourse }\end{array}$ & $\begin{array}{l}\text { Prevalent in all transcripts but } \\
\text { diversity between groups in terms } \\
\text { of who exhibited this type of talk } \\
\text { the most - some groups were more } \\
\text { consistent than others. In attempting } \\
\text { to explain or justify links made on } \\
\text { concept map, there was a sense of } \\
\text { ease and automaticity that always } \\
\text { consisted of integrated and relevant } \\
\text { ideas. Authentic contexts were often } \\
\text { drawn on for explanations. }\end{array}$ & $\begin{array}{l}\text { S1: Well the concept of } \\
\text { constructivism to me is that it's a } \\
\text { form of learning and teaching } \\
\text { where teachers, instead of being } \\
\text { the expository type... who stands } \\
\text { out the front and says "blah, } \\
\text { blah"... the constructivist teacher } \\
\text { designs experiences where they } \\
\text { capitalise on what the students } \\
\text { already know, and goes from } \\
\text { there. So on the video ... the first } \\
\text { thing [the teacher] did was to get } \\
\text { the kids to discuss the kinds of } \\
\text { energy they already knew about } \\
\text {... (CA1/2G2) }\end{array}$ \\
\hline $\begin{array}{l}\text { Extended } \\
\text { abstract } \\
\text { discourse }\end{array}$ & $\begin{array}{l}\text { A few, but not many instances of } \\
\text { this talk and only in two groups. } \\
\text { Comments made in these instances } \\
\text { were rich, on a par with an expert's } \\
\text { definition and creative. Attempts } \\
\text { made to construct own theories } \\
\text { about aspects of concept maps. }\end{array}$ & $\begin{array}{l}\text { S1: ... so like for the qualitative } \\
\text { conception for reading you'd } \\
\text { look for personal interpretations } \\
\text {... So like the person plus the text } \\
\text { would give you the } \\
\text { interpretation ... what I do with } \\
\text { my students. Like I'll give them } \\
\text { this little diagram of a stick } \\
\text { person, a book and a light globe } \\
\text { and this means that the person } \\
\text { plus the text gives you your own } \\
\text { meaning of the story. } \\
\text { S2: ... you're letting them form } \\
\text { their own opinions. (CA1/2G3) }\end{array}$ \\
\hline $\begin{array}{l}\text { Meta- } \\
\text { cognitive } \\
\text { discourse }\end{array}$ & $\begin{array}{l}\text { Evident throughout all transcripts. } \\
\text { In many instances, the concept map } \\
\text { was used as a metacognitive } \\
\text { prompt. Based on the formation of } \\
\text { the map, groups would identify } \\
\text { areas that needed clarification. } \\
\text { Maps were used to indicate the } \\
\text { progress being made by the group. } \\
\text { Evidence that groups would } \\
\text { monitor each student's effort and } \\
\text { give encouragement to keep on task. }\end{array}$ & $\begin{array}{l}\text { S1: Guys, I'd really like to know a } \\
\text { bit more about levels of } \\
\text { processing. Where's the note card } \\
\text { for it? (CA1/2G4) } \\
\text { S1: Why haven't we got anything } \\
\text { about prior knowledge here? } \\
\text { S2: We do it's in the note card for } \\
\text {... no its not. } \\
\text { S3: What should we put it with? } \\
\text { What about ... (CA1/2G3) }\end{array}$ \\
\hline
\end{tabular}

Each category above represented a type of conceptual discourse that contributed in its own way to the groups' learning outcomes. Social discourse allowed group members to gauge each others' commitment to and perceptions of the learning situation while procedural discourse operationalised the task and computer demands. Prestructural discourse enabled the students to pool their knowledge resources and articulate misconceptions, and foundational discourse provided the basic infrastructure upon which relational discourse could take place. With 
sound understandings of the intricate relationships between concepts in place, extended abstract discourse allowed some individuals to attain higher levels of thought while metacognitive discourse mediated the entire collaborative experience.

However, even though each type of discourse was essential to the overall learning process, the socio-cognitive processes behind each one varied in complexity. For example, social, procedural and prestructural discourse was generally representative of lower order socio-cognitive processes whereas foundational, relational, extended abstract and metacognitive discourse was representative of higher order socio-cognitive processes. Therefore, for the computer to have enhanced learning, it was hypothesised that these more structural oriented socio-cognitive processes would prevail within group collaborations.

The graphs in Figure 2 provide an overview of the extent to which foundational, relational, extended abstract and metacognitive sociocognitive processes were evident in comparison to the other categories during the three recording sessions and for each group. This discourse has been categorised as 'structural knowledge'.

Given that the nature of conceptual change involves the gradual adjustment and reorganisation of central concepts (Tyson, Venville, Harrison \& Treagust, 1997), a considerable degree of prestructural discourse was expected to prevail in the first recording session, as the groups grappled with largely unfamiliar subject matter. Similarly, it was expected that procedural discourse would dominate initially given the groups' inexperience with Inspiration and computers as learning tools. These types of discourse were then expected to subside as a stronger focus on structural discourse emerged alongside the groups' growing proficiency with the concepts and the computer software and hardware.

This scenario was partially evident in that substantial structural discourse was apparent in the final recording sessions for each group. During this class, between 50 and 70 percent of all four groups' discussions featured discourse which was indicative of either foundational, relational, extended abstract or metacognitive knowledge. There was a definite sense of group solidarity where collaborations between the computer and the students facilitated the development and consolidation of conceptual relationships. However, this relationship with the computer was not automatic. At the beginning of the semester, discussions were held at the computer, where thoughts and ideas were developed first, then recorded in the concept map. Eventually, students began to incorporate the computer more into their groups and as such discussions were held around and with the concept map (Crook, 1994). 
Group G1

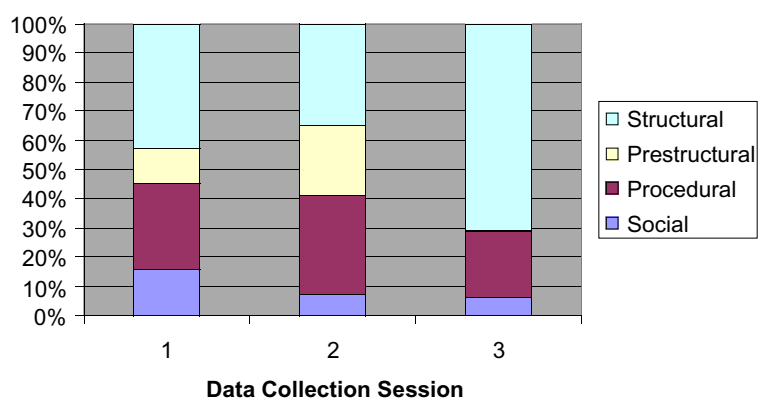

Group G2

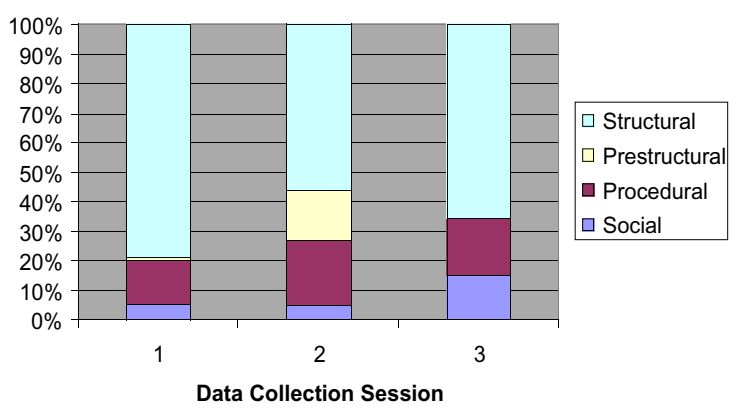

Group G3

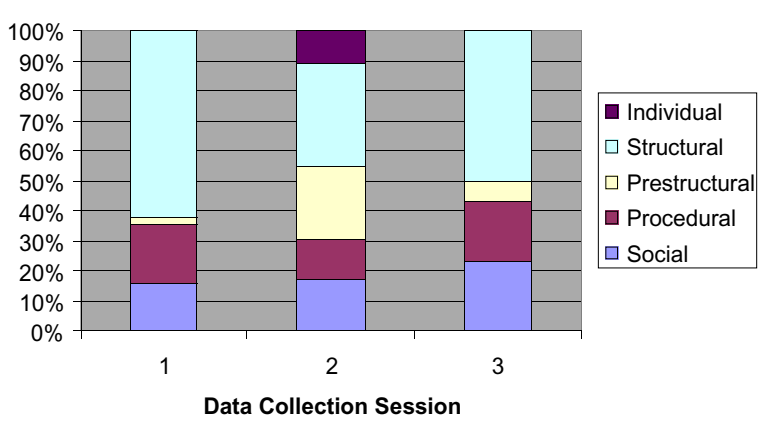


Group G4

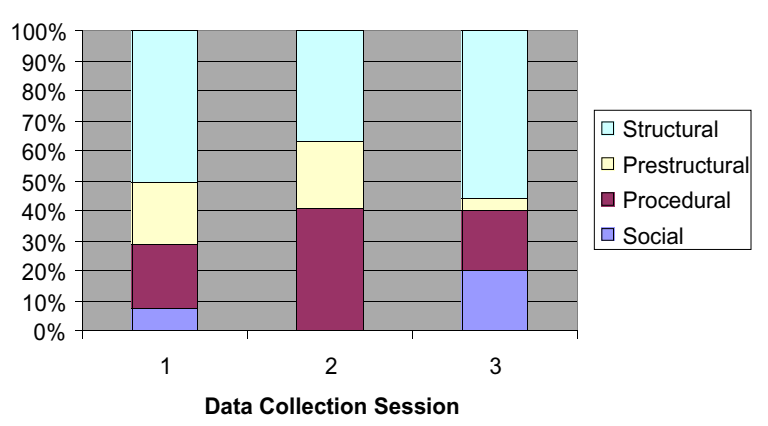

Figure 2: Comparison of discourse within groups across the three recording sessions

There was no prestructural discourse evident in the third recording session for groups one and two, and only a small amount for groups three and four, which perhaps is suggestive of the groups' attainment of higher levels of understanding of concepts, or at the very least, their efforts to reach higher levels of understanding. The presence of approximately 20 percent of procedural discourse in all groups was largely in relation to technical problems with the computer hardware which occurred that day. While still relatively low, social discourse was at its highest for most groups during the third recording session. Interestingly, this social discourse was largely in relation to on task discussions that were so in depth that the groups often lost focus and direction.

There is no consistent pattern, however, across the first two recording sessions, nor across all four groups. For example, in the first recording session, group two participated in structural discourse almost 80 percent of the time. Their explanations and challenges were firmly grounded in existing knowledge which facilitated discussions that were comprehensive and typically situated in authentic situations. This finding is believed to be an outcome of both the group's previous knowledge of the topic being studied, and the distributed learning environment within which this collective memory was nurtured into well-connected knowledge structures.

Although still relatively high (about 55\%), structural discourse for the same group decreased in the following recording session. Prestructural discourse, on the other hand, was higher indicating the group's efforts to come to terms with new concepts. This was the case for all groups during the second recording session within which the topic of Learning strategies 
was being tackled for the second consecutive week. It can be inferred from the data, therefore, that this topic was perhaps a little more complex than the others. Consequently, each group devoted between 15 and 30 percent of their time trying to understand individual facts before integrating them into meaningful, interconnected conceptions.

Procedural discourse was also prevalent in the second recording session, particularly for groups one and four. In looking at the specific breakdown for these two groups, most of the procedural oriented discussion was in relation to the task. In both instances, these groups misinterpreted the task requirements and consequently spent up to 40 percent of their time trying to rectify the situation.

Group three also experienced some degree of difficulty in their efforts to collaborate during the second recording session. The outcome was a patchwork of various types of discourse that did not really dominate in any one area. Although there was more structural discourse in comparison to the other categories, the data suggests that it was largely in relation to their recognition that the concepts could be integrated but no definite relationships were made. Furthermore, there were brief instances where this group entered into dialogue that was more individually oriented than distributive and collaborative. Given that the unit of analysis was the sociocognitive processes to emerge from group discussions, these instances were simply classified as 'individual discourse'.

On the whole, however, it can be said that structural discourse had a strong presence in each recording session. When presented with a task or concept, there was consistent evidence in the data that groups reflected on their combined prior knowledge, made inferences about it, challenged each other, determined the implications of interrelationships and made attempts to fit ideas it into a coherent explanations. As was indicated in Table 2, this process typically occurred in the presence of the concept mapping tool, which clearly provided the group with visual representations of their developing understandings.

Given that the socio-cognitive processes needed to construct these understandings required a higher level of thinking, it can be inferred that the learning environment was supportive in this instance. In other words, the DLE facilitated the potential of the ICT to be realised, in that the students were encouraged to work with Inspiration in an intellectual partnership. However, Inspiration's potential within this partnership was augmented and amplified by the connections students made to a range of other resources also. Table 3 provides a summary of the resources that constituted this intellectual partnership. 
Table 3: Summary of resources that constitute the intellectual partnership

\begin{tabular}{|l|l|}
\hline \multicolumn{1}{|c|}{ Resource } & \multicolumn{1}{c|}{ Category } \\
\hline Inspiration & Physical / Symbolic \\
\hline Peers & Social \\
\hline Teacher & Social \\
\hline Learning Strategies / Metacognition & Intellectual \\
\hline Notes / Text / Readings & Physical / Symbolic \\
\hline Whiteboard & Physical / Symbolic \\
\hline
\end{tabular}

\section{Conclusions}

It can be concluded from these findings that the characteristics that presuppose the development of structural knowledge are present due to a form of socially organised intervention with the computer. Collaborative group work with and around the computer has fostered the conditions that lead to quality learning outcomes in a distributed learning environment. Interaction with the computer appears to have mediated the groups' attempts to place structure and coherency in their dialogue, identify gaps in their understandings, and take the appropriate steps towards integrating knowledge.

The visual component of the computer clearly served a useful purpose. The images produced by Inspiration provided a basis for discussion amongst the groups. Conversations held about the meaning and interpretation of these images enabled the groups to uncover their partial understandings of concepts. This metacognitive facility was prominent throughout the semester as a means for groups to control and regulate their learning.

Additionally, it was apparent in this study that the teacher's role as a social resource in this collaborative environment was of central importance. Whereas some approaches to computer based learning threaten to remove the teacher from active participation in student learning, teacher intervention in this study was crucial. By participating in the groups" conversations, the teacher was able to determine the appropriate times at which she could share a level of expertise about the topic that would resolve cognitive disputes or extend understandings. This was particularly evident when the groups were engaged in dialogue representative of the more structurally oriented socio-cognitive processes. In these instances, the teacher was also able to monitor the groups' collaborative abilities and model techniques that facilitated the students' efforts to transact meanings and develop a common knowledge base.

Ferry, Kiggins, Hoban and Lockyer (2001) also found teacher input to be essential to computer mediated communications. In their attempts to 
provide teacher education students with a general view of the professional habits and obligations associated with primary school teaching, they devised a knowledge building community within which students communicated with each other using a range of collaborative computer technologies. They found that providing the appropriate conditions for this type of learning environment, as well as frequently monitoring student progress, is only half the battle. Regular contributions from the teacher are also integral to the development and maintenance of rich student dialogue and, subsequently, the construction of shared understandings.

Finally, it can be argued that this study was successful across a couple of platforms. Firstly, it promoted effective learning in teacher education classrooms, and secondly it modelled effective implementation strategies to students who will be responsible for integrating ICT in future K-12 classrooms. Previous studies have shown that the integration of ICT into teacher education courses without consideration of a sound implementation plan, have had little success. The DLE offers teachers a framework by which this implementation can be supported such that students are encouraged to maximise the potential of ICTs (and other resources) and develop rich intellectual learning partnerships.

\section{References}

Biggs, J.B. \& Collis, K.E. (1989). Towards a model of school-based curriculum development and assessment: Using the SOLO Taxonomy. Australian Journal of Education, 33, 149-161.

Cole, M. \& Engeström, Y. (1993). A cultural-historical approach to distributed cognition. In G. Salomon (Ed.). Distributed cognitions: Psychological and educational considerations (pp. 1-46). Cambridge: Cambridge University Press.

Crook, C. (1994). Computers and the collaborative experience of learning. London: Routledge.

Duffy, T.M. \& Cunningham, D.J. (1996). Constructivism: Implications for the design and delivery of instruction. In Jonassen, D.H. (Ed), Handbook of Research for Educational Communication and Technology. Simon and Schuster Macmillan: New York (pp. 170-198).

Ferry, B., Hedberg, J. \& Harper, B. (1998). How do preservice teachers use concept maps to organise their curriculum content knowledge? Journal of Interactive Learning Research, 9(1), 83-104.

Ferry, B., Kiggin, J., Hoban, G. \& Lockyer, L. (2001). Use of computer-mediated communication to form a knowledge-building community in initial teacher education. Paper presented at the Australian Association for Research in Education Conference, Perth. [verified 16 Mar 2006] http://www.aare.edu.au/01pap/fer01044.htm 
Hutchins, E. (2000). Distributed cognition. [viewed 30 May 2005]

http:/ / eclectic.ss.uci.edu/ drwhite/Anthro179a/DistributedCognition.pdf

Jonassen, D.H. (1992). What are cognitive tools? In P.A.M. Kommers, D.H. Jonassen \& T. Mayes (Eds), Cognitive tools for learning Berlin, Springer-Verlag.

Jonassen, D., Howland, J., Moore, J. \& Marra, R. (2003). Learning to solve problems with technology: A constructivist perspective (2nd Edition). Upper Saddle River, New Jersey: Merrill Prentice Hall.

Jonassen, D. \& Tessmer, M. (1996). An outcomes-based taxonomy for instructional systems design, evaluation, and research. Training Research Journal, 2, 11-46.

Knuth, R.A. \& Cunningham, D.J. (1993). Tools for constructivism. In T.M. Duffy, J. Lowyck \& D.H. Jonassen (Eds), Designing environments for constructive learning (pp.163-188). Berlin: Springer-Verlag.

Lincoln, Y. \& Guba, E. G. (1985). Naturalistic inquiry. Beverley Hills: Sage.

Maor, D. (2004). Pushing beyond the comfort zone: Bridging the gap between technology and pedagogy. In R. Atkinson, C. McBeath, D. Jonas-Dwyer \& R. Phillips (Eds), Beyond the comfort zone: Proceedings 21st ASCILITE Conference (pp. 572-576). Perth, 5-8 December.

http://www.ascilite.org.au/conferences/perth04/procs/maor.html

Marton, F., Dall'Alba, G. \& Beaty, E. (1993). Conceptions of learning. International Journal of Educational Research, 19, 277-300.

Miles, M.B., \& Huberman, A.M. (1994). Qualitative data analysis: An expanded sourcebook (2nd. ed.). Thousand Oaks CA: Sage.

Nickerson, R.S. (1993). On the distribution of cognition: Some reflections. In G. Salomon (Ed), Distributed cognitions: Psychological and educational considerations (pp 229-261). Cambridge: Cambridge University Press.

Pea, R.D. (1985). Beyond amplification: Using the computer to reorganise mental functioning. Educational Psychologist 20(4), 167-182.

Pea, R.D. (1993). Distributed intelligence and designs for education. In G. Salomon (Ed), Distributed cognitions: Psychological and educational considerations (pp. 47-87). Cambridge: Cambridge University Press.

Perkins, D.N. (1985). The fingertip effect: How information processing technology shapes thinking. Educational Researcher, 14(7), 11-17.

Perkins, D.N. (1992). Smart schools. Toronto: The Free Press.

Perkins, D. N. (1993). Person-plus: A distributed view of thinking and learning. In G. Salomon (Ed), Distributed cognitions: Psychological and educational considerations (pp. 88-110). Cambridge: Cambridge University Press. 
Resnick, L. (1996). Situated rationalism: The biological and cultural foundations for learning. Prospects, 26(1), 37-53.

Rogers, Y. (2004) An updated introduction to Distributed Cognition. To appear in The encyclopedia of language and linguistics 2nd Edition. [viewed 6 July 2004] http://www.slis.indiana.edu/faculty/yrogers/papers/Rogers_DCog04.pdf

Salomon, G. (1993). No distribution without individuals' cognition: A dynamic interactional view. In G. Salomon (Ed), Distributed cognitions: Psychological and educational considerations (pp. 111-138). Cambridge: Cambridge University Press.

Salomon, G. \& Perkins, D.N. (1998). Individual and social aspects of learning. Review of Research in Education, 23, 1-24.

Salomon, G., Perkins, D.N. \& Globerson, T. (1991). Partners in cognition: Extending human intelligence with intelligent technologies. Educational Researcher, 20(3), 29.

Siemens, G. (2004). Connectivism: A learning theory for the digital age. [verified $16 \mathrm{Mar}$ 2006] http:/ / www.elearnspace.org/Articles/connectivism.htm

Somekh, B. (2001). Methodological issues in identifying and describing the way knowledge is constructed with and without information and communications technology. Journal of Information Technology for Teacher Education, 10(1\&2), 157178.

Steketee, C. (2005). Integrating ICT as an integral teaching and learning tool into pre-service teacher training courses. Issues in Educational Research, 15(1), 101-113. http://education.curtin.edu.au/iier/iier15/steketee.html

Tyson, L.M., Venville, G.J., Harrison, A.G. \& Treagust, D.F. (1997). A multidimensional framework for interpreting conceptional change events in the classroom. Science Education, 81, 387-404.

Underwood, J.D.M. \& Underwood, G. (1990). Computers and learning. Oxford: Blackwell.

Carole Steketee $P h D$, Coordinator Graduate Diploma (Secondary)

Education, School of Education, The University of Notre Dame Australia,

19 Mouat Street (PO Box 1225), Fremantle, Western Australia 6959. Email: csteketee@nd.edu.au 